\title{
Agnès Maillot, L'IRA et le conflit nord-irlandais
}

\section{Michel Savaric}

\section{(2) OpenEdition}

1 Journals

\section{Édition électronique}

URL : https://journals.openedition.org/etudesirlandaises/7415

DOI : 10.4000/etudesirlandaises. 7415

ISSN : 2259-8863

\section{Éditeur}

Presses universitaires de Caen

\section{Édition imprimée}

Date de publication : 14 novembre 2019

Pagination : 160-162

ISBN : 978-2-84133-945-7

ISSN : 0183-973X

\section{Référence électronique}

Michel Savaric, "Agnès Maillot, L'IRA et le conflit nord-irlandais », Études irlandaises [En ligne], 44-1 |

2019, mis en ligne le 14 novembre 2019, consulté le 14 novembre 2022. URL : http://

journals.openedition.org/etudesirlandaises/7415; DOI : https://doi.org/10.4000/etudesirlandaises. 7415

\section{(c) (i) (2)(2)}

Creative Commons - Attribution - Pas d'Utilisation Commerciale - Partage dans les Mêmes Conditions 4.0 International - CC BY-NC-SA 4.0

https://creativecommons.org/licenses/by-nc-sa/4.0/ 
throughout the period and the Galway Races went ahead without interference in 1920 and 1921. McNamara is critical of the Volunteers in Galway, describing them as "often disorganised and frequently incompetent" in comparison to the IRA in other parts of the country. However, he does not hold back in his condemnation of the British forces either, accusing them of a campaign of assassination against leading Galway republicans, few of whom actually died in action. A series of killings by the army and police in 1920 and 1921, in which men were bundled out of their homes and later found dead, sometimes after torture, curbed IRA activity, but random murders of civilians turned public opinion against British rule and stimulated further resistance.

There is a welcome chapter on the effect of the revolution on Protestants in Galway which correctly rejects Peter Hart's thesis of ethnic cleansing and instead suggests a mixture of the breakdown of law and order combined with economic resentment inspired boycott, intimidation and violence against Protestants, particularly after the Truce of July 1921. The Protestant population of the county was already in decline well before the revolution, as was the population of the county as a whole, through relentless post-Famine emigration. Also welcome is the effort to illustrate the role played by women in the revolution, both inside and outside Cumann na mBan, although this inevitably suffers from the lack of records left behind and the low regard many contemporaries had for women's involvement. Relying on lists of Cumann na mBan to gauge female participation is not enough, as McNamara points out. The level of detail on local Volunteer companies is impressive, but there are some surprising omissions. For instance, while Liam Mellows' actions during the Rising are described in detail, once he flees to America in 1916 he largely vanishes from the work, and the longer-term effects of his intensely personal command in Galway are not analysed - an important factor, considering that the Volunteers in Galway idolised him, as the Witness Statements in the Bureau of Military History make clear. The book ends on a pessimistic note, stating that many of the political elite who were pushed aside in 1918, such as Máirtín Mór McDonagh, made a comeback in the 1920s and the people who participated in the revolution were forgotten. Further local examinations of the revolution in Ireland will ensure that they are not.

Bernard Kelly

\section{Agnès Maillot, L'IRA et le conflit nord-irlandais, Caen, Presses universi- taires de Caen, 2018, 346 p.}

L'autrice, enseignante-chercheuse à Dublin City University, avait déjà publié un ouvrage sur le même sujet en 2001 (IRA: les républicains irlandais aux Presses universitaires de Caen). Or, depuis cette époque, des changements considérables 
sont survenus: l'IRA a officiellement déposé les armes et le processus de paix est entré dans une nouvelle phase. En 2007, les unionistes du parti de Ian Paisley ont accepté de gouverner avec Sinn Féin et les institutions prévues par l'accord de 1998 ont pu fonctionner sans interruption pendant dix ans. Cette page tournée a permis de réinterroger le passé. Des témoignages sont apparus, des révélations ont émergé, des investigations ont été menées, si bien qu'on en sait beaucoup plus aujourd'hui sur cette organisation politique, violente et secrète. Ce deuxième ouvrage sur l'IRA était donc pleinement justifié; il ne s'agit pas d'une redite du premier.

Agnès Maillot retrace l'histoire de l'Irlande en même temps que celle de l'armée républicaine irlandaise. Elle rappelle la longue lignée d'organisations qui l'ont précédée dans la lutte pour une république irlandaise indépendante. L'armée de guérilla fondée en 1919 n'a pas réussi à obtenir cette complète indépendance du gouvernement britannique. Puis elle a perdu la guerre civile mais n'a pas cessé d'exister pour autant. Elle est devenue une armée de l'ombre. L'exposé de l'autrice sur la période allant de la fin de la guerre civile au début de la Deuxième Guerre mondiale, notamment sur les relations ambiguës et changeantes entre l'IRA et de Valera, est d'autant plus intéressant que cet épisode est peu connu.

L'IRA renaît une première fois de ses cendres après la guerre, lors de la campagne de la frontière de 1956 à 1962. Ces attaques, menées dans le nord à partir du sud, prennent fin dans le désintérêt général et l'absence totale de soutien populaire. L'essentiel de cet ouvrage est surtout consacré aux cinquante dernières années de l'existence de cette organisation, et à la fraction qui est devenue dominante après la scission de 1970: l'IRA provisoire (PIRA), plus présente dans le nord que dans le sud. On peut peut-être regretter, à ce sujet, le peu de place accordé à l'IRA officielle (OIRA), notamment pendant les deux années riches en événements de 1970 à 1972. Ainsi, il se pourrait que la mention de graffiti "IRA = I Ran Away», soi-disant apparus sur les murs des quartiers catholiques après l'été 1969 (voir p. 65), soit une création des historiographes de l'IRA provisoire pour justifier la scission. De même, l'autrice évoque la trajectoire de fondateurs de la PIRA comme Seán Mac Stíofáin, Ruairí Ó Brádaigh et Dáithí Ó Conaill mais ne mentionne pas des personnages marquants de l'OIRA comme Joe McCann, tué par les parachutistes le 15 avril 1972, dont les funérailles donnèrent lieu à un cortège de 5000 personnes et dont le souvenir n'est évidemment pas entretenu par l'actuel Sinn Féin.

Mais on ne peut faire à cet ouvrage le reproche d'être un plaidoyer pour l'IRA. Il se démarque des récits quasiment hagiographiques que l'on peut lire parfois comme certaines biographies de Bobby Sands ou certains articles d'anciens journalistes français. La façon dont les républicains ont su habilement négocier la fin de leur violence contre une intégration dans l'establishment britannique n'a pas été éludée. Les vingt-cinq dernières années et les controverses qui les ont émaillées - la question des disparus, ces personnes tuées en secret par l'IRA, et la possible implication de Gerry Adams, les expéditions punitives - ne sont pas oubliées.

L'avenir semble désormais appartenir à Sinn Féin même si, comme le rappelle l'autrice en introduction, l'IRA existe toujours (de même que toutes les autres 
organisations paramilitaires qui ont alimenté la chronique des Troubles). Le chapitre de la violence armée républicaine irlandaise semble clos mais on ne manquera pas de noter que le chapitre du Brexit semble ouvrir une nouvelle période d'incertitude quant à l'avenir constitutionnel de l'Irlande du Nord.

Michel SAVARIC 